\title{
SISTEM INFORMASI PENJUALAN PERUMAHAN DI HARMONI GALLERY BERBASIS JAVA
}

\author{
Rizaldi Taufiq ${ }^{1}$, Aprilia Sulistyohati ${ }^{2}$, Juliana $^{3}$ \\ 1,2,3 Teknik Informatika, Fakultas Teknik dan Ilmu Komputer, Universitas Indraprasta PGRI \\ Jalan Raya Tengah No 80, Kelurahan Gedong, Pasar Rebo, Jakarta Timur \\ 1rizaldi0710@gmail.com, ${ }^{2}$ aprilia6891@gmail.com, ${ }^{3 j u l i a n a j u l i 220 @ g m a i l . c o m ~}$
}

\begin{abstract}
ABSTRAK
Masalah yang ada di Harmoni Gallery yaitu sering mengalami kesulitan dalam pendataan customer dan rumah yang sudah terjual maupun belum terjual. Harmoni Gallery belum adanya pembuatan laporan penjualan dan pelayanan mereka hanya menggunakan rekap nota untuk laporan. Tujuan penelitian ini untuk menanggulangi permasalahan tersebut, yaitu dengan merancang sistem penjualan rumah secara terintegrasi dan terorganisir lebih baik dengan memanfaatkan teknologi informasi yang sudah berkembang pesat. Metodologi dalam penelitian ini menggunakan metode studi pustaka dan metode observasi dengan mengumpulkan data yang berhubungan dengan masalah - masalah yang hendak diteliti. Berdasarkan penelitian yang dilakukan, diperoleh hasil bahwa sistem informasi penjualan perumahan di harmoni gallery berbasis java, dapat memudahkan pekerjaan bagian admin dalam mendata data karyawan, data pelanggan, data rumah, data survey, transaksi cash, transaksi kredit dan pembayaran cicilan dengan mudah dapat melakukan pendataan dan penyimpanan data lebih aman dan terjamin.
\end{abstract}

Kata Kunci : Harmoni Gallery, Java, Netbeans

\begin{abstract}
The problem in Harmoni Gallery is that it often has difficulty collecting data on customers and houses that have been sold. Harmoni Gallery does not yet have a sales report, and their service only uses a recap of notes for essays. The purpose of this study is to overcome these problems, namely by designing an integrated and better-organized home sales system by utilizing information technology that has developed rapidly. The methodology in this research uses the literature study method and the observation method by collecting data related to the problems to be studied. Based on the research conducted, the results show that the information system for housing sales in the Java-based harmony gallery can facilitate the work of the admin section in recording employee data, customer data, house data, survey data, cash and credit transactions. Installment payments easily. Data storage is more secure and secure.
\end{abstract}

Key Word: Harmoni Gallery, Java, Netbeans

\section{PENDAHULUAN}

Perkembangan teknologi sekarang ini sangatlah berkembang dengan pesat, terutama dalam dunia teknologi komputer dan informasi yang semakin hari semakin terlihat kecanggihannya, keadaan ini memungkinkan para pengguna teknologi informasi membutuhkan teknologi yang dapat membantu dalam menyelesaikan masalah secara tepat dan akurat. Perlu kita ketahui bahwa didalam dunia bisnis, industri, badan usaha dan bidang lainnya sekarang sudah didukung oleh teknologi informasi. Dalam perkembangannya teknologi informasi selalu terkait dengan perkembangan sistem informasi. Teknologi informasi dipakai dalam sistem informasi untuk menyediakan informasi bagi para pemakai dalam rangka pengambilan
keputusan.

Sistem informasi yang baik akan meningkatkan aksesbilitas data yang tersaji secara tepat waktu dan akurat bagi para pemakai, dukungan sistem informasi dapat membuat sebuah organisasi atau perusahaan memiliki keunggulan yang kompetitif dan sistem informasi dapat mengembangkan berbagai produk, layanan dan kemampuan yang memberikan perusahaan keunggulan besar dan berorientasi solusi untuk tantangan organisasi atau perusahaan.

Harmoni Gallery merupakan salah satu solusi terbaik bagi sebagian besar masyarakat Indonesia yang ingin memiliki rumah yang bagus dan nyaman dengan 
harga yang terjangkau murah. Namun masalah dalam pengolahan data yang masih belum terkomputerisasi dan bukti transaksi masih berbentuk manual.

Masalah lain yang ada di Harmoni Gallery yaitu sering mengalami kesulitan dalam pendataan customer dan rumah yang sudah terjual maupun belum terjual. Harmoni Gallery belum adanya pembuatan laporan penjualan dan pelayanan mereka hanya menggunakan rekap nota untuk laporan.

Tujuan penelitian ini untuk menanggulangi permasalahan tersebut, yaitu dengan merancang sistem penjualan rumah secara terintegrasi dan terorganisir lebih baik dengan memanfaatkan teknologi informasi yang sudah berkembang pesat. Metodologi dalam penelitian ini menggunakan pendekatan kualitatif dengan mengumpulkan data yang berhubungan dengan masalah - masalah yang hendak diteliti.

Proses bisnis yang terdapat dalam Harmoni Gallery yaitu proses pendaftaran, proses pendataan pelanggan, proses pemesanan, proses pembayaran dan proses laporan. Berdasarkan latar belakang penelitian yang bertujuan untuk memberikan alternatif solusi kepada pemilik Harmoni Gallery, maka diperlukan suatu sistem aplikasi yang dapat meningkatkan kualitas pelayanan Harmoni Gallery untuk kepentingan pengumpulan data, mulai dari alur sistem yang berjalan sampai dengan aturan bisnis yang berlaku pada gallery tersebut. Setelah itu penulis melakukan dokumentasi, berupa pendataan bagian - bagian yang penting dari sistem pengelolaan pembelian rumah yang diperlukan sebagai bahan penelitian.

Teknologi informasi adalah suatu teknologi yang digunakan untuk mengolah data. Pengolahan itu termasuk memproses, mendapatkan, menyusun, menyimpan, memanipulasi data dalam berbagai cara untuk menghasilkan informasi yang berkualitas, yaitu informasi yang relevan, akurat dan tepat waktu. Oleh karena itu dengan penerapan teknologi informasi ini akan memberikan manfaat bagi pengelola aplikasi sistem informasi penjualan rumah agar dapat menjalankan proses bisnisnya lebih cepat dan tepat serta mengurangi adanya human error sehingga dapat meningkatkan mutu dan kualitas dalam pelayanan terhadap pelanggan.

Dalam rangka mendapatkan hasil penelitian yang baik, selain melakukan peneltian secara langsung penelitian juga melakukan kajian pustaka dari penelitian yang telah dilakukan sebelumnya, beberapa hasil penelitian yang menjadi acuan adalah penelitian dari (Setiawan \& Informatika, 2021) dengan judul Simulasi Kredit Perumahan Menggunakan Metode Perhitungan Suku Bunga Bank Dki Cabang BSD dengan hasil penelitian penerapan sistem manual ke dalam aplikasi dengan membuat database aplikasi agar dalam penerapan kedalam aplikasi lebih mudah karena setiap data sudah bisa diinput diaplikasinya begitupun dengan laporan.

Penelitian dari (Kristanto, 2020) dengan judul Analisa Dan Perancangan Sistem Informasi E-Booking Property Berbasis Android dengan hasil penelitian rancangan aplikasi yang dapat memudahkan perusahaan properti menyebarkan informasi perumahan baru secara cepat dan akurat.

Penelitian dari (Nuraidah, 2019)dengan judul Usulan Strategi Pemasaran Perumahan Menggunakan Analisis SWOT dan Matriks QSPM dengan hasil penelitian alternatif strategi berdasarkan analisis matrik SWOT seperti strategi pengembangan produk, strategi penetrasi pasar, memberi lahan perluasan pembangunan.

Penelitian dari (Fauzi et al., 2021) dengan judul Implementasi Laravel Dan White Hat SEO Pada Pembuatan Website Banghm Jogja Properti menggunakan Pemasaran website memanfaatkan Search Engine Optimization (SEO) White Hat SEO untuk memperluas cakupan pengunjung website. Hasil akhir penelitian ini sebuah media pemasaran berbasis website sebagai media penjualan serta penyebaran informasi dengan fungsi mengelola data produk iklan dan artikel berita. 
Penelitian dari(Herdiansah et al., 2020) dengan judul Rancang Bangun Sistem Pemasaran Properti Berbasis Web. Metode analisa sistem yang ada saat ini menggunakan metode analisis SWOT. Dalam proses perancangan system menggunakan Unified Modeling Language (UML) untuk membuat perancangan sistem pemasaran. Penelitian ini telah menghasilkan sebuah sistem informasi pemasaran property berbasis web yang membantu proses pemasaran Akila Residence.

Penelitian dari (Rohmawati, Siti Oktavia; Daniati, Erna; Firliana, 2018) dengan judul Sistem Informasi Pemasaran Perumahan. Penelitian ini menggunakan metode waterfall dengan cara menggambarkan pendekatan yang sistematis dan juga berurutan pada pengembangan perangkat lunak.

Penelitian dari (Saragih, 2020) dengan judul Strategi Penjualan Usaha Perumahan. Stategi penjualan dan pemasaran di Perumahan Asri Indah harus terus ditingkatkan dan melakukan pemikiran yang disesuaikan dengan keadaan sekarang seperti peningkatan mutu bangunan dengan bentuk dan desain yang minimalis yang disukai konsumen dan promosi lainnya yang merangsang konsumen untuk membeli rumah.

Penelitian dari (Diningrat, 2015) dengan judul Segregasi Spasial Perumahan Skala Besar: Studi Kasus Kota Baru Kota Harapan Indah (KHI) Bekasi. Dengan menggunakan metode pendekatan deduktif-kualitatif, tulisan ini menunjukkan bagaimana segregasi spasial tersebut terjadi dalam dua bentuk, yakni (1) segregasi spasial antara kota baru dengan wilayah sekitarnaya dan (2) segregasi spasial antar kluster dalam kota baru.

Penelitian dari (Sidik et al., 2017) dengan judul Perancangan Sistem Administrasi Perumahan pada PT.Gunung Berlian Nusantara Prabumulih. Rancangan ini menggunakan pemograman PHP dan basis data MySQL dengan alat bantu perancangan menggunakan UML (Unified Modelling
Language). Adapun metode pengembangan sistem yang digunakan adalah metode Prototype.

Penelitian dari (Rafin, 2013) Perancangan Sistem Informasi Perumahan Berbasis Web Pada Pt.Cipta Jaya Inhil. Rancangan ini menggunakan pemograman PHP dan basis data MySQL dengan alat bantu perancangan menggunakan DFD (Data Flow Diagram). Adapun metode pengembangan sistem yang digunakan adalah metode System Life Cycle.

\section{METODE PENELITIAN}

Tehnik pengumpulan data merupakan tahap yang sangat penting, karena hanya dengan mendapatkan data yang tepat maka proses penelitian akan berlangsung sampai peneliti mendapatkan jawaban dari perumusan masalah yang sudah ditetapkan. Data yang dicari harus sesuai dengan tujuan penelitian. Untuk memperoleh gambaran mengenai data yang dibutuhkan, maka tehnik pengumpulan data dalam "Sistem Informasi Penjualan Perumahan di Harmoni Gallery Berbasis Java" adalah sebagai berikut:

1. Metode Studi Pustaka Metode ini merupakan metode yang dilakukan untuk mendapatkan informasi terkait dengan permasalahan yang akan diteliti. Peneliti mendapatkan data dengan cara membaca dan mempelajari artikel, karya ilmiah, jurnal ilmiah atau sumber lain yang berhubungan dengan tema yang dipilih kemudian merangkum dan mengutip untuk dijadikan sebagai acuan bahan penelitian.

2. Metode Observasi Pada kegiatan observasi ini merupakan proses pengamatan dan penelitian langsung ke dalam kegiatan guna mendapatkan data dan informasi serta mengetahui permasalahan atau kendala yang dihadapi dalam proses sistem yang sedang berjalan.

\section{HASIL DAN PEMBAHASAN}

Aturan bisnis yang diusulkan penulis pada Harmoni Gallery adalah sebagai berikut :

1. Penginputan data karyawan Bagian karyawan melakukan peng-inputan data karyawan serta jabatannya melalui form karyawan ketika ada karyawan baru. 
2. Penginputan data rumah

Kemudian Admin melihat daftar rumah yang tersedia dan harga yang sudah tertera di aplikasi untuk kemudian ditawarkan kepada pelanggan.

3. Penginputan data pelanggan Admin melakukan penginputan data pelanggan yang ingin membeli rumah.

4. Penginputan data transaksi cash Admin melakukan proses transaksi cash untuk pelanggan yang ingin membeli rumah secara cash.

5. Penginputan data transaksi kredit Admin melakukan proses transaksi kredit untuk pelanggan yang ingin membeli rumah secara kredit

6. Proses survey

Surveyor akan melakukan survey pekerjaan dan tempat tinggal kepada pelanggan yang melakukan transaksi secara kredit.

7. Proses Pembayaran cicilan

Pelanggan akan melakukan pembayaran cicilan perbulan dan di input oleh karyawan di form pembayaran cicilan.

8. Pembuatan laporan

Pemilik Harmoni Gallery mendapatkan laporan data rumah, laporan transaksi penjualan dan laporan data survey dari admin yang bertugas.

\section{Dekomposisi Fungsi Sistem yang Diusulkan}

Dekomposisi fungsi dimaksudkan untuk mengetahui gambaran fungsi-fungsi proses dan bentuk masukan serta keluaran yang terdapat pada sistem yang akan dijalankan. Berikut ini gambaran dari dekomposisi fungsi sistem:

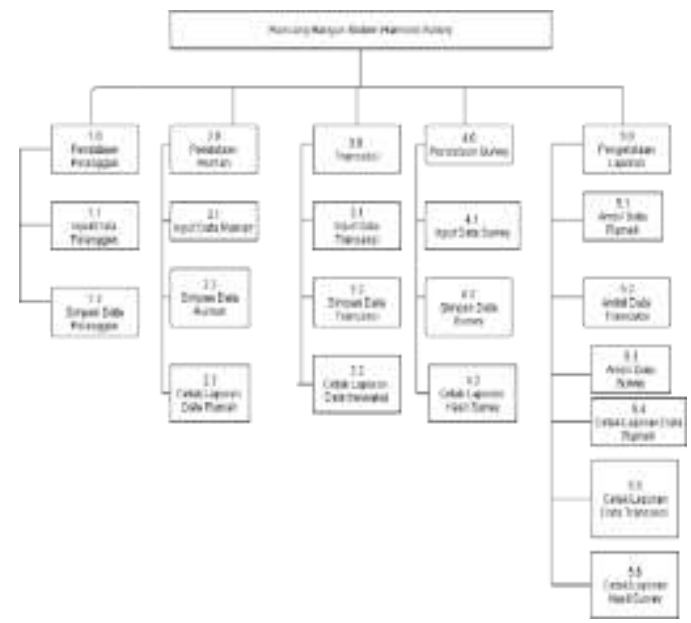

Gambar 1. Dekomposisi Sistem Diusulkan
Diagram Konteks yang Diusulkan

Aliran data sistem yang diusulkan berikutnya digambarkan pada diagram konteks berikut :

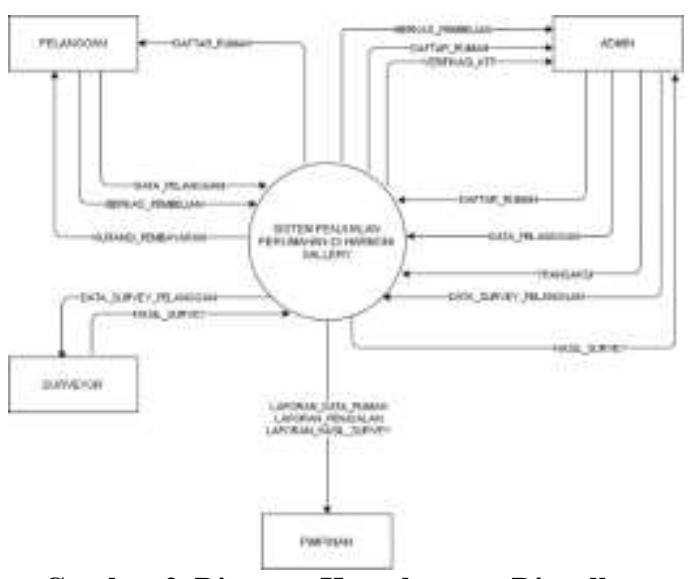

Gambar 2. Diagram Konteks yang Diusulkan

Entity Relationship Diagram (ERD) "Entity Relationship Diagram (ERD) adalah memodelkan struktur data dan hubungan antara data, untuk menggambarkanya digunakan beberapa notasi dan symbol". (Simarmata, 2010)

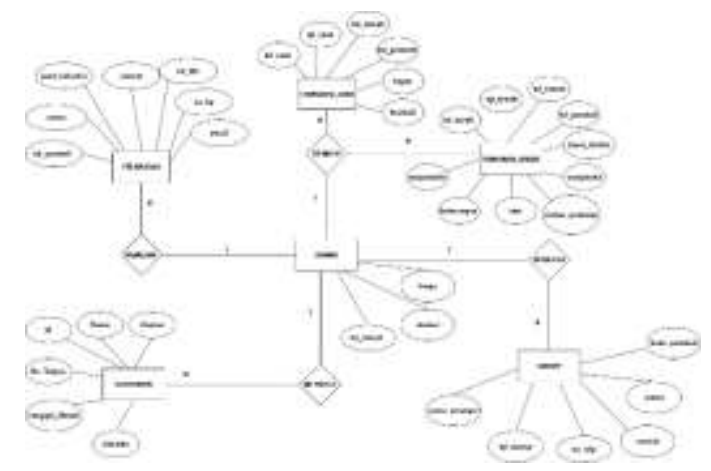

Gambar 3. Entity relationship Diagram (ERD)

\section{Tampilan Layer Login}

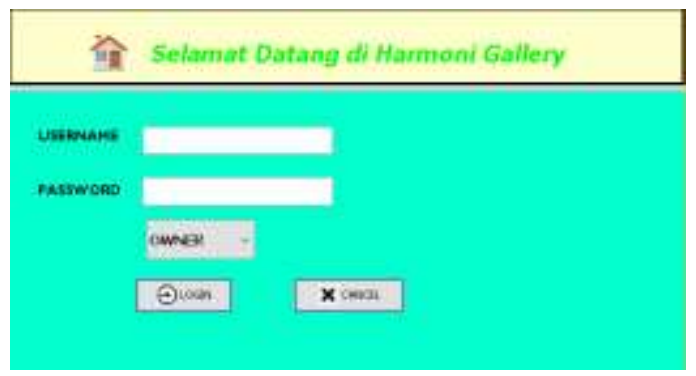

Gambar 4. Tampilan Layar Menu Login

Menu login Admin digunakan sebagai kata kunci sebelum admin memasuki program utama. Menu ini bertujuan untuk mengamankan program supaya tidak dapat diakses oleh orang lain kecuali admin. 


\section{Tampilan Layer Menu Utama}

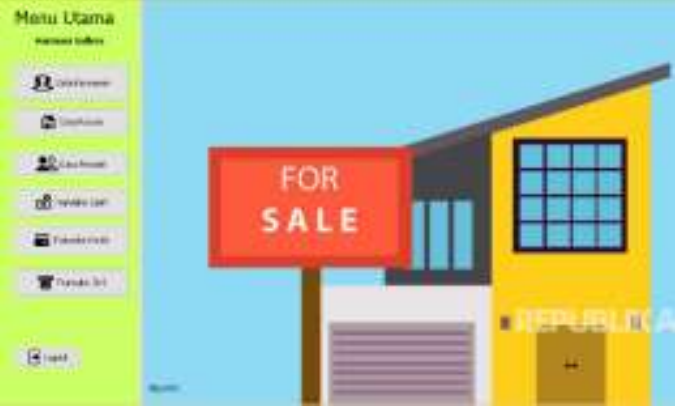

Gambar 5. Tampilan Layar Menu Utama

Menu diatas menampilkan tampilan menu utama sistem informasi pemesanan barang. Menu ini berfungsi untuk memasukkan datadata yang berkaitan dengan Data rumah, Data Karyawan, Data Pelanggan, Data Survey, Transaksi Cash, Transaksi Kredit Dan Pembayaran Cicilan.

\section{Tampilan Layer Data Pelanggan}

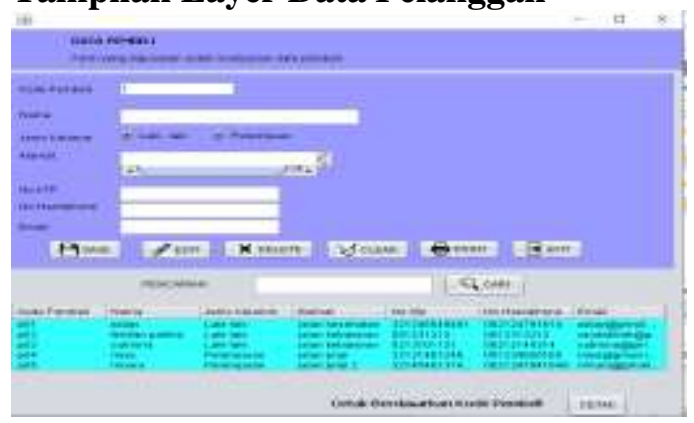

Gambar 6. Tampilan Layer Data Pelanggan

Pada Tampilan layer ini admin dapat menginput Data Pelanggan, Melakukan perubahan Data Pelanggan serta dapat menghapus Data Pelanggan.

\section{Tampilan Layer Data Karyawan}

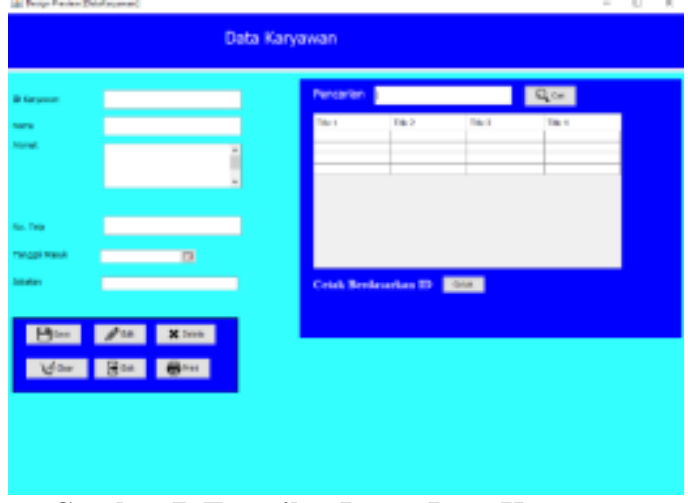

Gambar 7. Tampilan Layer Data Karyawan

Pada tampilan layer ini admin dapat menginput Data Karyawan, siapa saja yang sudah mulai bekerja dan sudah resmi menjadi karyawan di Harmoni Gallery.

\section{Tampilan Layer Data Rumah}

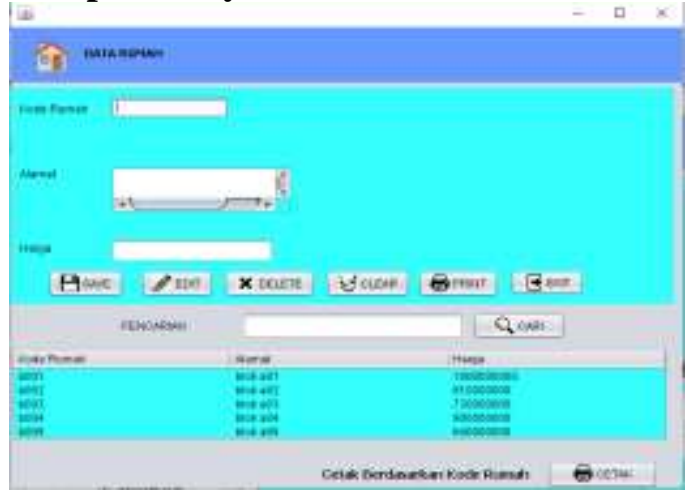

Gambar 8. Tampilan Layer Data Rumah

Pada Tampilan layer ini admin dapat menginput Data rumah, Melakukan perubahan Data Rumah serta dapat menghapus Data Rumah.

\section{Tampilan Layer Transaksi}

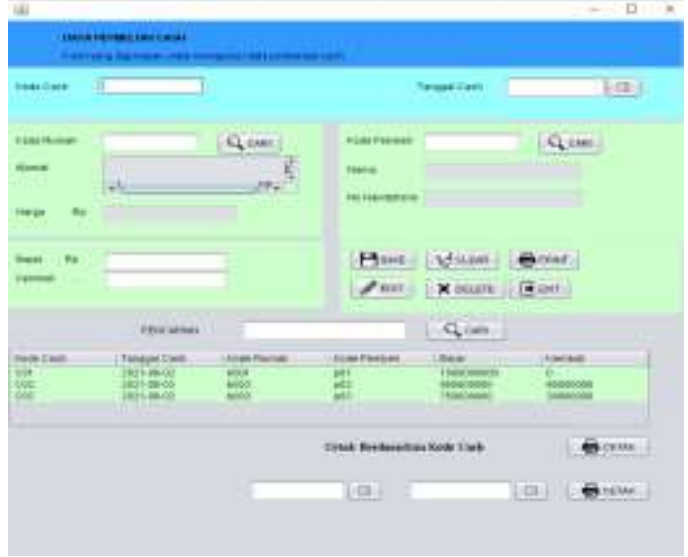

Gambar 9. Tampilan Layer Transaksi

Pada Tampilan layer ini admin dapat menginput Transaksi Cash, Melakukan perubahaan pada Transaksi Cash serta dapat menghapus Transaksi Cash.

\section{Tampilan Laporan Transaksi}

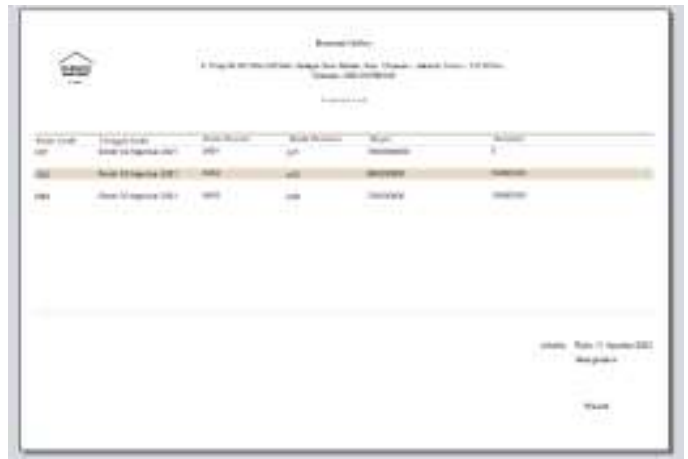

Gambar 10. Tampilan Output Transaksi

Pada Tampilan ini Admin dapat memberikan Laporan Transaksi Pinjaman 
kepada Pelanggan dan Owner Harmoni Gallery. Laporan ini bisa muncul setelah melakukan transaksi yang dilakukan pada saat transaksi cash.

\section{SIMPULAN DAN SARAN}

Berdasarkan hasil pembahasan dan penelitian mengenai aplikasi Sistem Informasi Penjualan Perumahan di Harmoni Gallery dilihat bahwa penggunaan komputer semaksimal mungkin dapat membantu pekerjaan dalam pendataan, pencatatan ataupun pembuatan laporan yang sifatnya berulang-ulang, dengan adanya sistem yang telah terkomputerisasi akan mendapatkan beberapa kesimpulan, yaitu sebagai berikut : Perancangan sistem Sistem Informasi Penjualan Perumahan di Harmoni Gallery selama ini masih menggunakan sistem manual, dengan dibuatnya sistem yang baru, yang di rancang menggunakan bahasa pemrograman Java Neatbeans IDE, dengan menggunakan Database MySQL, sehingga pekerjaan lebih efektif dan efisien dalam pengolahan data.

Komputerisasi sebagai alternatif pemecahan masalah dalam menangani masalah-masalah yang terdapat pada sistem Sistem Informasi Penjualan Perumahan di Harmoni Gallery yang sedang berjalan saat ini diharapkan dapat membantu dan merupakan salah satu alternatif pemecahan masalah. Sehingga proses pengolahan data yang ada lebih terkontrol dengan sistem komputerisasi ini sangat memudahkan saat pembuatan laporan dan penyimpanan data dengan harddisk dapat menghemat tempat dan biaya serta terjamin keamanannya karena dapat digunakan berulang-ulang kali dan diperbaharui.

Sejalan dengan sistem usulan yang penulis buat, maka demi tercapainya tujuan dan sasaran yang diharapkan, maka penulis dapat memberi saran sebagai berikut:Sistem ini dikembangkan kembali dalam hal desain atau penambahan database sesuai perkembangan kebutuhan pengolahan data penjualan rumah. Dilakukan evaluasi secara berkala untuk mengetahui apakah sistem ini berjalan dengan baik atau tidak dan apakah diperlukan perbaikan-perbaikan, serta apakah sistem ini telah memenuhi keinginan pemakai sistem. Perlu dilakukan perawatan terhadap sistem ini sehingga dapat berfungsi dalam jangka waktu yang cukup lama.

\section{DAFTAR PUSTAKA}

Diningrat, R. (2015). Segregasi Spasial Perumahan Skala Besar: Studi Kasus Kota Baru Kota Harapan Indah (KHI) Bekasi. Jurnal Perencanaan Wilayah Dan Kota, 26(2), 111-129. https://doi.org/10.5614/jpwk.2015.26. 2.4

Fauzi, M. F., Wibowo, O. A., \& Setiawan, D. (2021). Implementasi Laravel Dan White Hat SEO Pada Pembuatan Website Banghm Jogja Properti. 4(1), 1-7.

Herdiansah, A., Handayani, T., \& Yunita, E. (2020). Rancang Bangun Sistem Pemasaran Properti Berbasis Web. 22(1), 8-17. https://doi.org/10.33557/jurnalmatrik. v22i1.834

Kristanto, fajar M. (2020). Analisa Dan Perancangan Sistem Informasi EBooking Property Berbasis Android Pendahuluan Studi Literatur. 2, 540556.

Nuraidah, D. D. (2019). Usulan Strategi Pemasaran Perumahan Menggunakan Analisis SWOT Dan Matriks QSPM (Studi Kasus: Perumahan Green Hill, Pasir Putih). https://doi.org/10.31227/osf.io/n4f68

Rafin, A. (2013). Perancangan Sistem Informasi Perumahan Berbasis Web Pada Pt.Cipta Jaya Inhil. Jurnal SISTEMASI, 2(4), 49-59. http://sistemasi.ftik.unisi.ac.id/index.p $\mathrm{hp} / \mathrm{stmsi} /$ article/view/140/0

Rohmawati, Siti Oktavia; Daniati, Erna; Firliana, R. (2018). Sistem Informasi Pemasaran Perumahan. 3, 1-9.

Saragih, R. A. (2020). Strategi penjualan usaha perumahan. 1, 171-178.

Setiawan, H. S., \& Informatika, T. (2021). Simulasi Kredit Perumahan Menggunakan Metode. 2(2), 128-133.

Sidik, A., Sutarman, \& Marlenih. (2017). Perancangan Sistem Informasi Penjualan Perumahan Citra Raya. Perancangan Sistem Informasi Penjualan Perumahan Citra Raya, 7(1), 56-65. 